CAN SOCIAL CAPITAL AFFECT SUBJECTIVE POVERTY IN EUROPE? AN EMPIRICAL ANALYSIS BASED ON A GENERALIZED ORDERED LOGIT MODEL

Giuseppina Guagnano, Elisabetta Santarelli and Isabella Santini 


\title{
CAN SOCIAL CAPITAL AFFECT SUBJECTIVE POVERTY IN EUROPE? AN EMPIRICAL ANALYSIS BASED ON A GENERALIZED ORDERED LOGIT MODEL*
}

\author{
Giuseppina Guagnano* \\ Elisabetta Santarelli* \\ Isabella Santini ${ }^{\star}$
}

\begin{abstract}
In a previous exploratory analysis of the 2009 EU-SILC survey and the Eurostat statistics database, the authors tried to reveal to what extent self-perceived poverty in Europe is associated with specific household socioeconomic characteristics and particular aspects of household/community social capital endowment, by means of a multiple correspondence analysis (Guagnano et al., 2014). Such an analysis has appeared to be a useful tool to disclose the primary risk factors of family poverty status and, in particular, it showed that self-perceived poverty (measured by the proxy variable "ability to make ends meet") is strongly associated not only with household socioeconomic characteristics, but also with the indicators commonly recognized as elementary proxies of household/community social capital endowment.

The aim of the present paper is to capture the effect of social capital on household subjective poverty. More precisely, a generalized ordered logit model is estimated, in order to highlight to what extent: a) self-perception of poverty in Europe is affected by the respondent/household socioeconomic characteristics and by household/community social capital endowment; b) probabilities corresponding to response categories vary according to different levels of predictors; c) differences among European countries in terms of self-perception of poverty may be related to different levels of social capital endowment.

The results are very encouraging and confirm that social capital could be used by local and central governments as a further key function, in addition to the traditional socioeconomic ones for planning poverty reduction policies .
\end{abstract}

Key words: subjective poverty, social capital, public policies, EU-SILC, generalized ordered logit model.

Classification JEL: I32, D10, I38

\section{INTRODUCTION}

According to the most widely accepted definition suggested by the World Bank Social Capital Initiative Program research group, social capital includes the

\footnotetext{
*The present work has been developed within the research "Perception of poverty. Individual, household and social environmental determinants" led by Isabella Santini at SAPIENZA University of Rome, partially supported by 2010 Italian M.I.U.R. grants (prot. C26A10WW49).

"Department of Methods and Models for Economics, Territory and Finance, SAPIENZA University of Rome, Via del Castro Laurenziano, 900161 Rome, Italy ( e-mail: $\square$ giuseppina.guagnano@uniroma1.it ; esantarelli@inwind.it ; Isabella.santini@uniroma1.it).
} 
institutions, the relationships, the attitudes and values that govern interactions among people and contribute to economic and social development (Grootaert and van Bastelaer, 2002). This definition synthesizes the different points of view expressed by Putnam (1993), Coleman (1990), Olson (1982) and North (1990) and implies that living in a society characterized by model and cooperative behavior, and where trust replaces suspicion and fear, can have a systematic positive effect on individuals' perception of poverty, as their socioeconomic vulnerability is reduced as well as the resources they need to deal with risk and to avert major losses (Helliwell, 2001).

In a previous study (Guagnano, Santarelli, Santini, 2013) the authors showed that self-perceived poverty in European countries is associated with at least three aspects: the household socioeconomic conditions; the degree of family and social distress; the level of social capital endowment. These results have important policy implications: actually, public policies can improve household welfare and alleviate poverty not only through traditional income support measures but also by enhancing the development of the desirable forms of social capital in the areas where households live (i.e. social networks and connections which cross boundaries of social class, ethnicity and gender and which strengthen mutual trust; voluntary initiatives and so on). As a matter of fact, in countries such as, for example, Portugal, Greece and Italy, characterized by poor household economic well-being but also by low social capital endowment, poverty reduction policies could be more effective if they reconciled traditional income support programs with measures facilitating development of desirable forms of social capital.

The subsequent objective, the aim of this paper, is then to measure and quantify the effect of social capital on self-perceived poverty and to examine if the relevant differences evident among European countries can also be due to different social capital endowments. In order to pursue this aim, a generalized ordered logit model (Williams, 2006) is carried out on data from the 2009 EU-SILC survey.

The paper is organized as follows: section 2 describes the data and the methodology used, section 3 presents the results and section 4 provides some concluding remarks and future research lines.

\section{DATA AND METHODOLOGY}

The analysis is based on data from the 2009 cross-sectional EU-SILC survey ${ }^{1}$, in order to pursue the objectives outlined in section 1.The household subjective

\footnotetext{
${ }^{1}$ EU-SILC is the Eurostat project on Income and Living Conditions which involves all the 27 European countries. EU-SILC is the reference source for comparative studies on income distribution, poverty and social exclusion at European level (Eurostat, 2009 and 2010; Santini and De Pascale, 2012a and 2012b) with the purpose of monitoring household economic and social conditions for aware planning of economic and social policies (Clemenceau et al., 2006).
} 
poverty is measured by the proxy categorical variable ability to make ends meet, with the following categories: with great difficulty; with difficulty; with some difficulty; fairly easily; easily; very easily.

The possible determinants of subjective poverty, considered in the analysis, are listed in the Appendix (tables A1 and A2) and describe, respectively,

1) The respondent/household socioeconomic characteristics ${ }^{2}$ : age, gender, marital status, education, employment status, low work intensity status, branch of activity, risk of poverty and social exclusion, general health, house/flat size, tenure status, dwelling type, reasons for changing dwelling, household type, equivalized disposable income, poverty and deprivation indicator, financial burden of housing cost, debts, family/children allowances, social exclusion, housing allowances, cash and alimonies received. Some of these variables are not statistically significant and/or have too many missing values and thus they have not been included in the generalized ordered logit models discussed in section $3^{3}$;

2) The household/community social capital endowment ${ }^{4}$. In particular, combining the elementary social capital indicators listed in Table A2, we have defined three complex indexes, one for each of the following categories:

- social behaviour (SB), related to those socioeconomic characteristics that facilitate/hinder the development of social and economic cooperative behavior;

- social relationships (SR), related to potential and actual degree of social relationships;

- territorial and environmental context (TC), related to those context characteristics which are significant determinants of social capital formation.

Elementary indexes belonging to the same category have been synthesized through a simple arithmetic mean, hypothesizing that they are perfectly and mutually replaceable as they measure different aspects of the same phenomenon. Furthermore, an overall social capital index has been obtained from these three complex indexes; now a simple geometric mean has been used, as this kind of aggregation implies a lower interchangeability of categories.

To capture the relation between the response variable and the predictors listed above we estimate a generalized ordered logit model $^{5}$ (Williams, 2006), that is an

EU-SILC provides two types of data, cross-sectional and longitudinal over a four- year period (EU-SILC uses a four-years rotational design).

2Respondent's socioeconomic characteristics are included to take into account the features of the person who answers, on behalf of the whole family, to the household questionnaire and, in particular, to the question on ability to make ends meet.

${ }^{3}$ These variables are: low work intensity status, branch of activity, risk of poverty and health of respondent; reasons for changing dwelling, household type, work intensity status, regular interhousehold cash received, alimonies received.

${ }^{4}$ Despite some shortcomings, the EU-SILC cross-sectional survey represents an important reference source for comparative studies aiming at measuring the effect of social capital on household economic well-being, especially because they provide comparable and high quality cross-sectional indicators for all the 27 European countries (see, for further details, Santini and De Pascale, 2012a,b).

${ }^{5}$ A generalized ordered logit model has to be applied as one of the main assumptions in ordered response models, the so called proportional odds assumption, is not satisfied here. 
ordered model whose estimated parameters are not the same for each response category, but some of them (not necessarily all) could vary across categories.

\section{RESULTS}

The analysis consists in estimating three different models, which have in common all the predictors referred to respondent/household socioeconomic characteristics:

the first one, from now on say M1, doesn't include any other predictor and is estimated only for comparative purpose;

the second one, say M2, includes in addition the overall social capital index, to measure the global effect of social capital on the response probabilities;

the third one, say M3, includes the three sectorial complex indexes, to account for the possible differential effect of each aspects of social capital.

Estimates obtained for the more general specification (M3), considering the category 'very easily' as the base category, are listed in the Appendix (Table A3).

All the estimated regression parameters are significant for at least one response category and the global performance of the model can be judged satisfactory, especially if we consider that the response categories are six and the percentage of "very easily" responses is very low (4.7\% of total responses), making it more difficult to correctly predict this category ${ }^{6}$.

Percentages of correctly predicted responses, obtained for each model, are listed in Table 1. It can be noted the general improvement in the performance of estimated models, going from the simpler to the more general one, which is not so obvious with the inclusion of additional predictors as it is for the log-likelihood function.

This improvement also occurs for each response categories, except for with some difficulty and very easily; in these two cases, in effect, information on social capital seems to make predictions even slightly worst. On the contrary, the greater improvement occurs for the first two categories.

Marginal effects of each independent variable, controlling for the remaining ones, are coherent with expectations and robust according to the three models. So, for example, probabilities of difficult and very difficult in ability to make ends meet increase with age, if the respondent is unemployed, if the family is at risk of poverty, severely materially deprived, with debts and financial burden of housing cost, receives income by people aged under 16 and allowances; conversely, these probabilities decrease with growing educational level and dimension of dwelling (in number of rooms).

\footnotetext{
${ }^{6}$ As a matter of fact, it is worth noting that if the dependent variable had only three response categories (with great difficulty or with difficulty; with some difficulty or fairly easily; easily or very easily), losing, however important details, the overall percentage of correctly predicted values increases of almost $45-50 \%$ on average than in the model with six responses..
} 
On the other side, probabilities of the categories easily and very easily increase if the respondent is working, with high level of education and free accommodation for dwelling.

The most interesting result is that all the social capital indicators show significant effects on the response variable. In particular, both the effect of the overall social capital index in model M2 (see Fig. 1), and the effects of the three sectorial indexes used in model M3 (see Fig. 2-4) are positive on the upper categories probabilities and negative on the lower categories ones; in other words, with growing values of social capital endowment European families' ability to make ends meet increases.

As to cross-country comparison based on results from model M3, in figures 5-6 probabilities of the categories with great difficulty and, respectively, very easily are plotted by country, in descending order. It can be seen that, for the very difficult category, countries with the higher probabilities are Greece, Cyprus, Portugal and Ireland. It is interesting to note that Greece also occupies the first position as to the probabilities of difficult category and the lower positions as to the probabilities of the remaining categories and its social capital index value lies below the European average. On the other side, for the category very easily countries with the higher probabilities are Sweden, Finland, Netherlands and Denmark; we can note that Finland also appears among the first positions as to the probabilities of the categories fairly easily and easily and the lower positions in the remaining cases and its social capital index value lies above the European average.

Another example of how differences standing out among European countries are also imputable to different social capital endowments refers to estimated probabilities of the category with some difficulty from the three models: in model M1, countries with higher probabilities are Lithuania, France, Italy, Slovenia and Ireland; in models M2 and M3, instead, when we consider social capital indexes, Estonia takes place of Ireland and really Ireland shows higher values than Estonia for all the social capital indexes. This evidence seems to confirm the crucial role that social capital could have in policies and strategies adopted by central and local governments to reduce poverty, as already outlined in Guagnano, Santarelli, Santini (2013). Thus, in countries characterized, on average, by poor economic conditions but also by low social capital endowment, policies aimed at poverty reduction could be more effective if they reconciled traditional income support programs with measures which facilitate and support the development of desirable forms of social capital.

\section{CONCLUSIONS}

This paper aims at showing if and to what extent self-perceived poverty in European countries is related with household socioeconomic characteristics and household/community social capital endowment in order to disclose the primary 
risk factors of family poverty. The analysis proves the existence of a relationship with both groups of possible determinants. If the strong link between household poverty status and socioeconomic characteristic is one of the most wellestablished results found in the empirical literature (Helliwell, 2001), the significant relationship between social capital and self-perception of poverty is less obvious and constitutes the core result of the analysis. Hence, not only do household socioeconomic characteristics play a crucial role in conditioning self-perception of poverty, but also household/community social capital endowment. More precisely, increasing household and community social capital endowment increases European households' ability to make ends meet. This result has direct and important implications for poverty reduction policies: as a matter of fact, in order to enhance household economic well-being, governments could also facilitate the development of desirable forms of social capital, in addition to the application of traditional income support measures. If the EU-SILC survey provided more social capital indicators with greater territorial detail, relationships between social capital and household poverty could be described and captured in their entirety, thus helping policy-makers considerably to promote suitable poverty reduction strategies.

From the statistical point of view, further research should have to cope with the possible endogeneity of social capital indicators, given that it is almost certainly measured with errors. In this case the research should investigate the possibility of including instrumental variables to obtain consistent estimates and more reliable results. 
Table 1: Percent correctly predicted, by response category and kind of estimated model

\begin{tabular}{|l|c|c|c|}
\hline \multirow{2}{*}{ Response category } & \multicolumn{3}{|c|}{ M1 } \\
\cline { 2 - 4 } & $\begin{array}{l}\text { Without any social } \\
\text { capital index }\end{array}$ & $\begin{array}{l}\text { M2 } \\
\text { With overall social } \\
\text { capital index }\end{array}$ & $\begin{array}{l}\text { With three sectorial } \\
\text { social capital } \\
\text { indexes }\end{array}$ \\
\hline With great difficulty & 47.26 & 47.60 & 47.85 \\
\hline With difficulty & 33.02 & 33.45 & 33.60 \\
\hline With some difficulty & 64.37 & 64.33 & 64.14 \\
\hline Fairly easily & 46.53 & 46.96 & 47.19 \\
\hline Easily & 37.50 & 37.52 & 37.57 \\
\hline Very easily & 14.44 & 14.34 & 14.23 \\
\hline Total & 46.86 & 47.06 & 47.11 \\
\hline
\end{tabular}


Fig. 1: Estimated Probabilities by Overall Social Capital Index

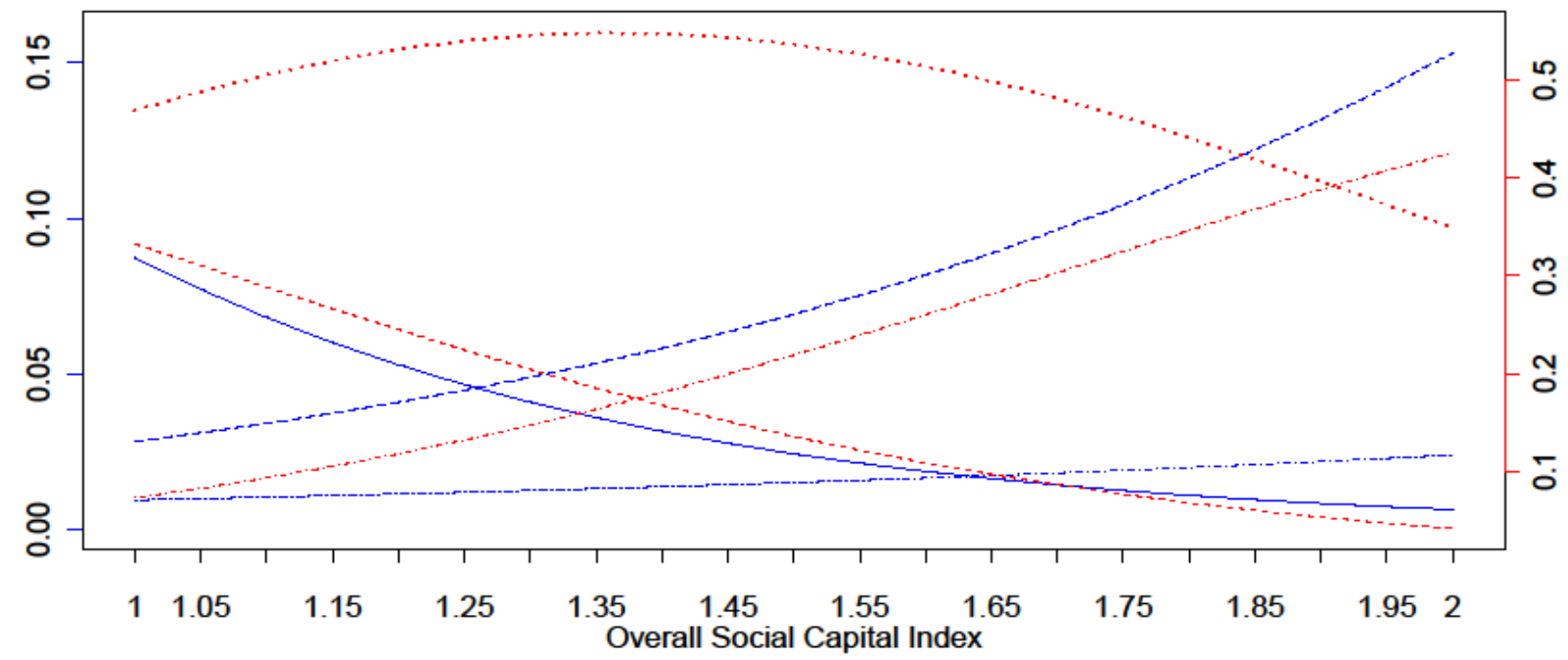

— GreatDifficulty ---- Difficulty _...... SomeDifficulty..... Fair $\quad$--- Easy $\quad$-.--. VeryEasy

Fig. 2: Estimated Probabilities by Social Behaviour Index

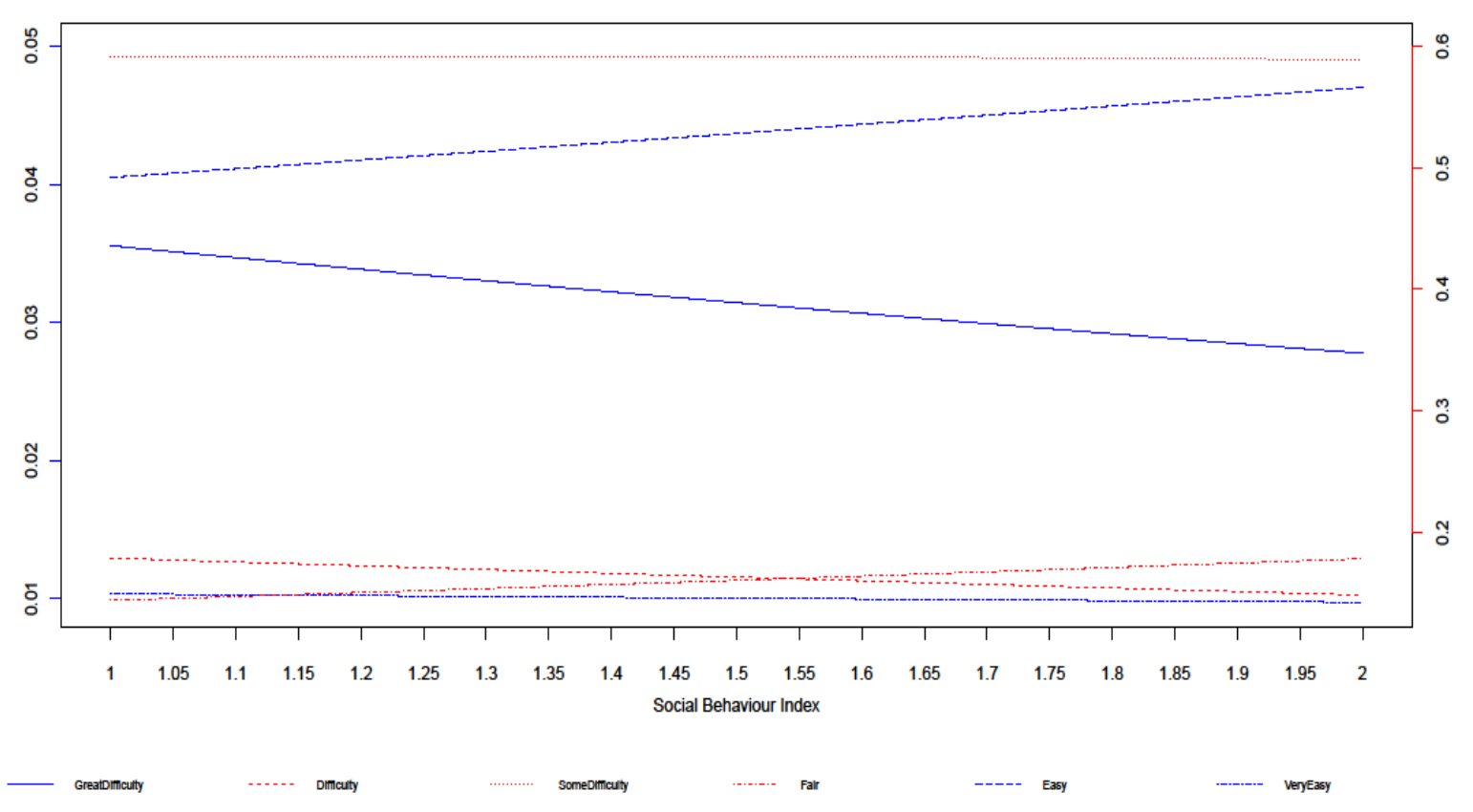




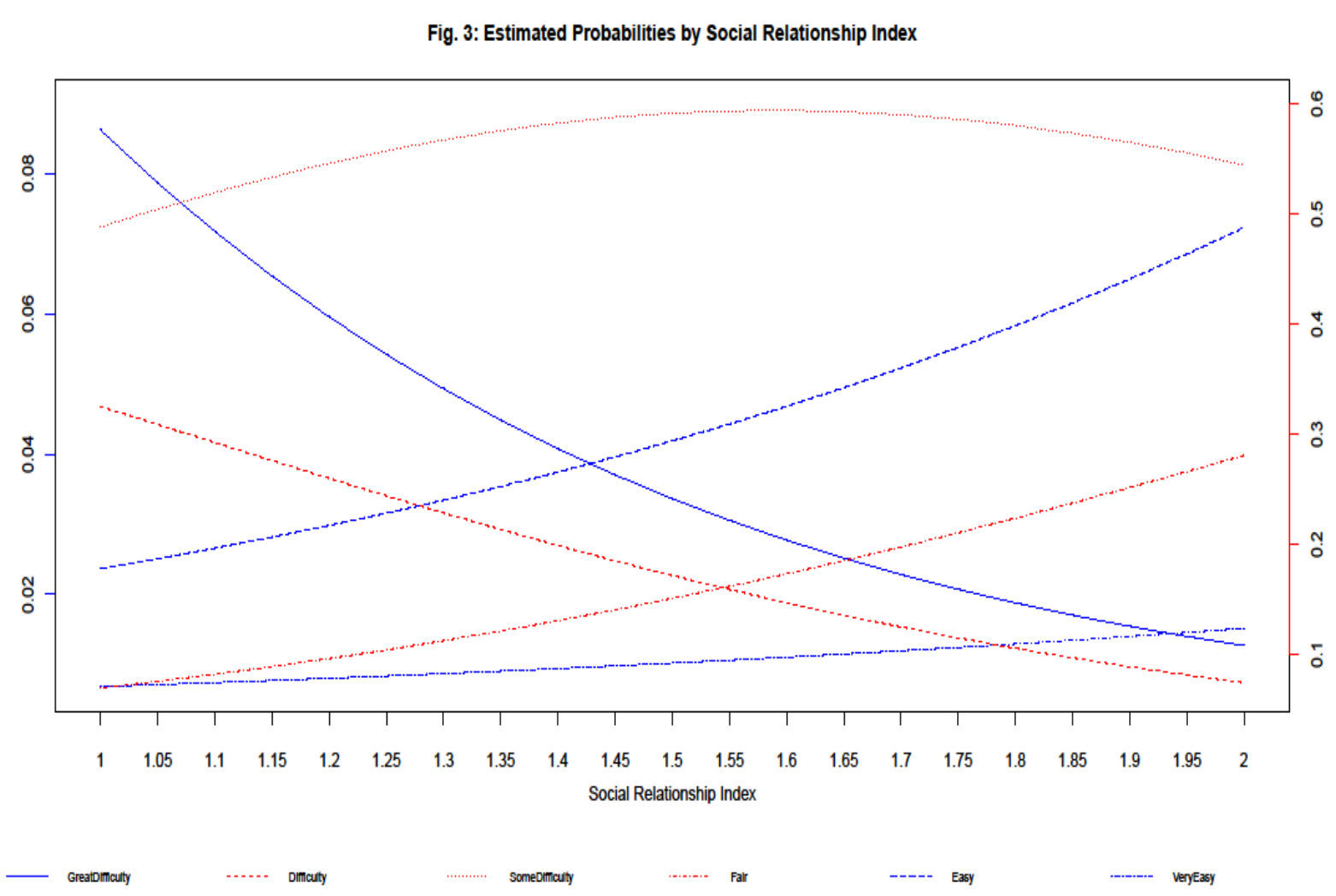

Fig. 4: Estimated Probabilities by Territorial Context Index

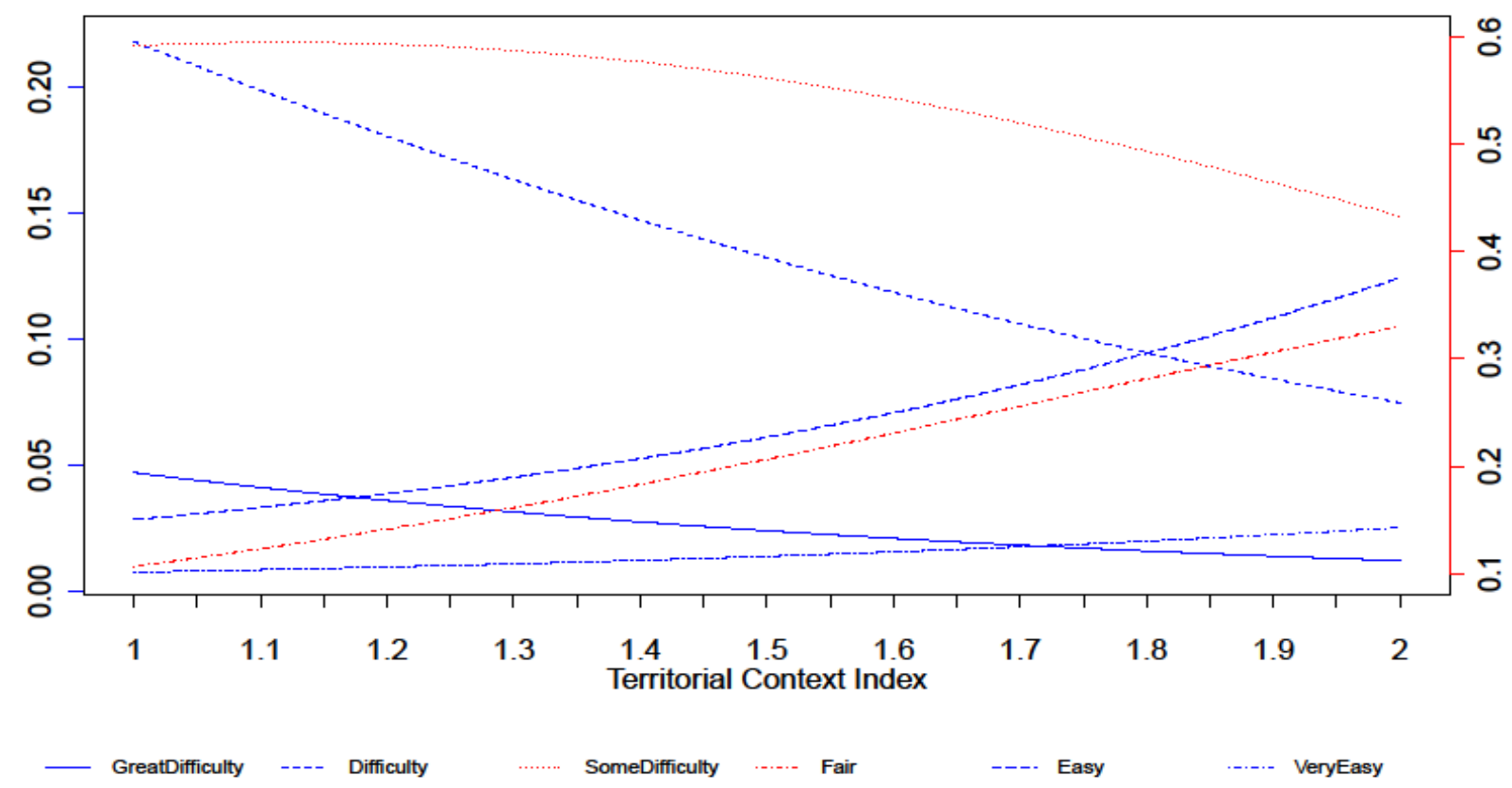


Fig. 5: Probabilty of category "with great difficulty", by country

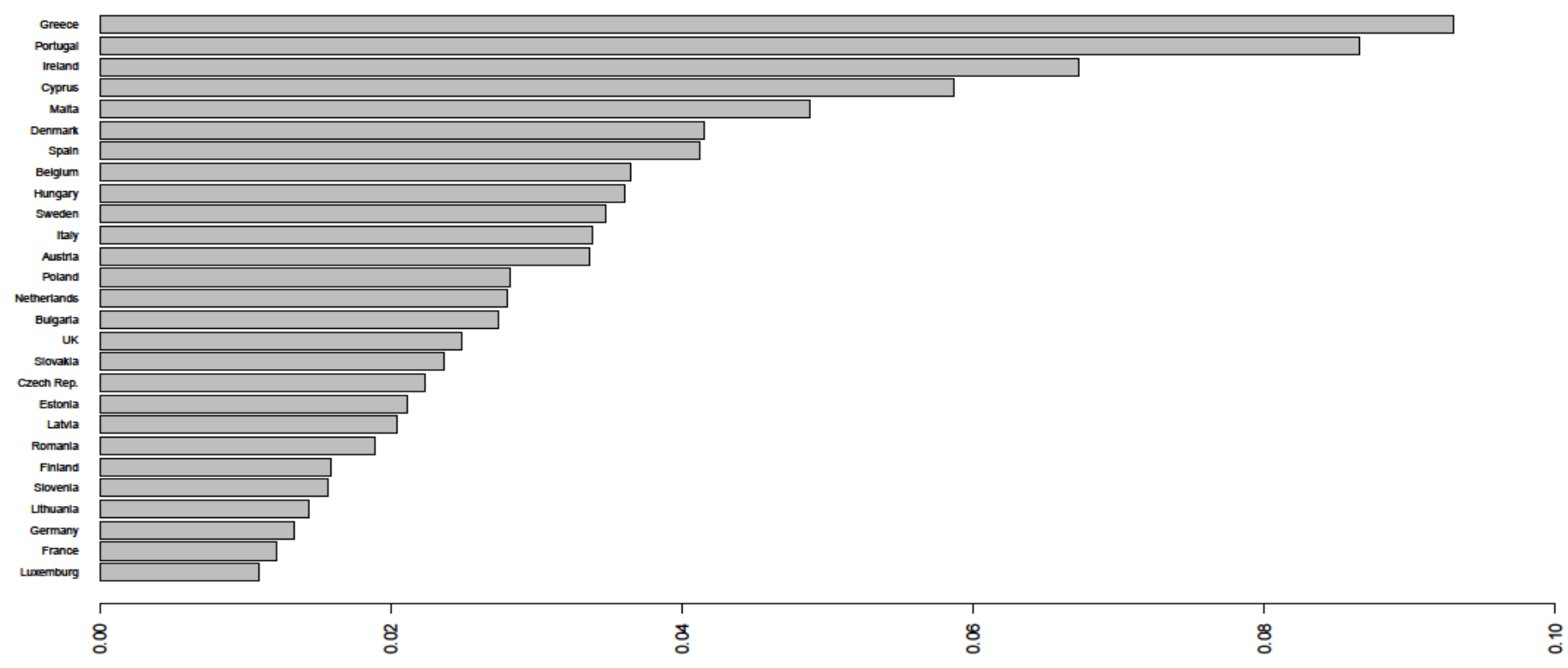


Fig. 6: Probabilty of category "very easily", by country

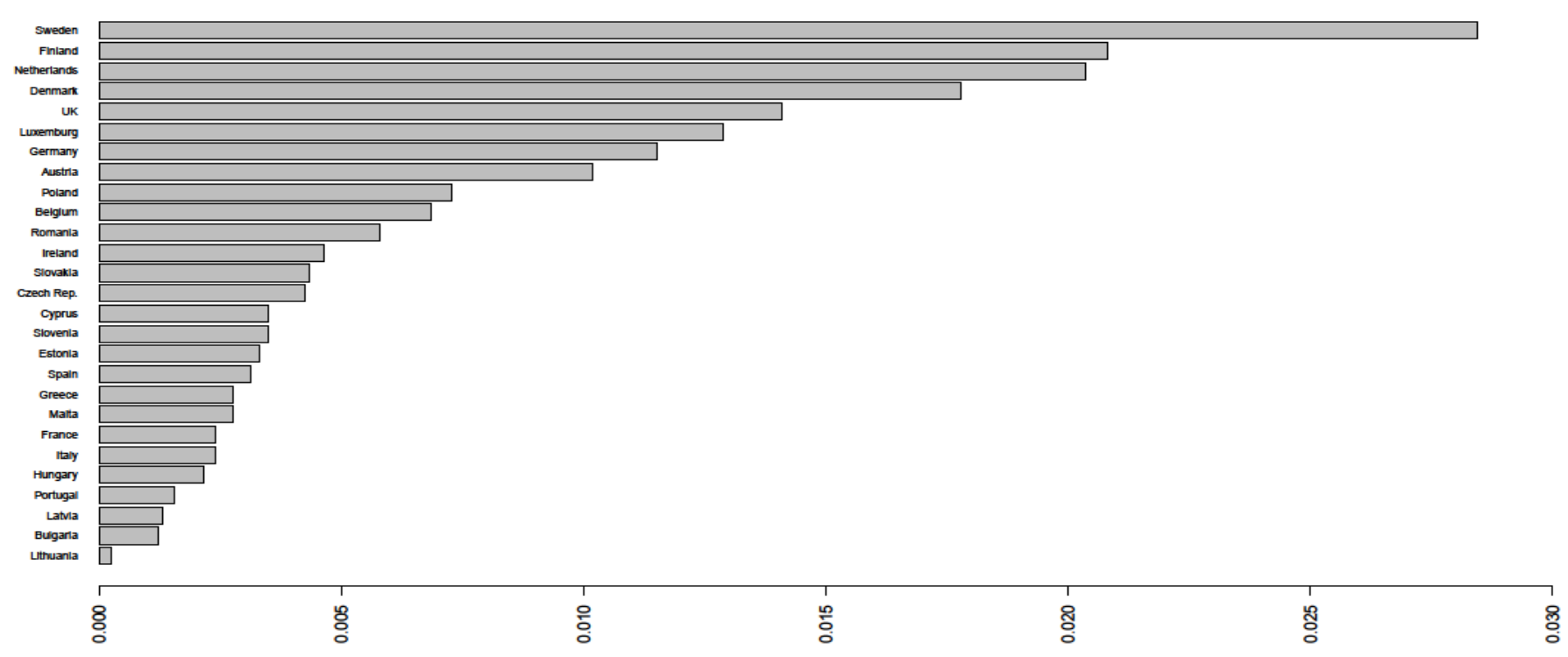


References

Clemenceau A., Museux J.-M. and M. Bauer (2006). EU-SILC (Community Statistics on Income and Living Conditions): issues and challenges. Paper presented at the Eurostat and Statistics Finland International conference "Comparative EU Statistics on income and living conditions: issues and challenges", Helsinki, November, 6-7.

Coleman J. (1990). Foundation of Social Theory. The Belknap Press of Harvard University, Cambridge MA.

Eurostat (2009). EU-SILC 065 (2009 operation). Description of target variables: cross-sectional and longitudinal 2009 operation (Version January 2010).

Eurostat (2010). Income and living conditions in Europe, ed. by Anthony B. Atkinson and Eric Marlier, Luxembourg.

Grootaert C., van Bastelaer T. (2002).The role of social capital in development: an empirical assessment - Cambridge: Cambridge University Press .

Guagnano G., Santarelli E., Santini I. (2014).The role of social capital in self-perception of poverty. An exploratory analysis. Annals of the Department Methods and Models for Economics, Territory and Finance. Patron ed., Bologna (forthcoming) .

Helliwell J.F. (2001). Social capital, the economy and well-being. In K. Banting. A. Sharpe. F.StHilaire (Eds.). The Review of Economic Performance and Social Progress. Institute for Research on Public Policy and Centre for the Study of Living Standards, (pp. 55-60). Montreal and Ottawa.

North D. C. (1990). Institutions. Institutional change and economic performance. Cambridge: Cambridge University Press.

Olson M. (1982). The rise and the fall of nations growth. stagflation and social rigidities. New Haven: Yale University Press.

Peterson B., Harrel F. E. (1990). Partial proportional odds models for ordinal response variables. Applied Statistics, 39 (2), pp. 205-217

Putnam R. (1993). Making Democracy Work: Civic Traditions in Modern Italy. Princeton University Press. Princeton (with Leonardi. R. and Nanetti. R.).

Santini I., De Pascale A. (2012a). Social capital and its impact on poverty reduction: measurement issues in longitudinal and cross-country comparisons. Towards a unified framework in the European Union. Working Paper Department of Methods and Models for Economics, Territory and Finance, SAPIENZA University of Rome, 101, pp. 1-47.

Santini I., De Pascale A. (2012b). Social capital and household poverty in Europe. Working Paper Department of Methods and Models for Economics, Territory and Finance, SAPIENZA University of Rome, 109, pp 1-35.

Williams R. (2006). Generalized ordered logit/partial proportional odds models for ordinal dependent variables, Stata Journal, 6, 1: 58/82. 


\section{APPENDIX}

Table A1 - Respondent and household socio-economic characteristics (Source: EU-SILC 2009)

\begin{tabular}{|c|c|c|}
\hline Label & Variable name & Categories \\
\hline AGE & Age & $\begin{array}{l}<24 \\
25-29 \\
30-34 \\
35-39 \\
40-44 \\
45-49 \\
50-54 \\
55-59 \\
60-64 \\
65-79 \\
80+\end{array}$ \\
\hline GEN & Gender & $\begin{array}{l}\text { Male } \\
\text { Female }\end{array}$ \\
\hline MST & Marital status & $\begin{array}{l}\text { Never married } \\
\text { Married } \\
\text { Separated or divorced } \\
\text { Widowed }\end{array}$ \\
\hline EDU & Educational qualification $^{1}$ & $\begin{array}{l}\text { Low } \\
\text { Medium } \\
\text { High }\end{array}$ \\
\hline EMP & Employment status & $\begin{array}{l}\text { Working } \\
\text { Unemployed } \\
\text { Retired } \\
\text { Inactive }\end{array}$ \\
\hline LWI & Low work intensity status & $\begin{array}{l}\text { No LWI } \\
\text { LWI } \\
\text { Agriculture } \\
\text { Industry } \\
\text { Construction } \\
\text { Wholesale retail } \\
\text { Transport and storage } \\
\text { Hotels and restaurants } \\
\text { Information and communication } \\
\text { Financial and insurance activities } \\
\text { Real estate. renting and business activities } \\
\text { Public administration. defense. social security } \\
\text { Education } \\
\text { Health and social work } \\
\text { Other } \\
\text { Not working }\end{array}$ \\
\hline RISK & At risk of poverty or social exclusion & $\begin{array}{l}\text { Not at risk } \\
\text { At risk of poverty } \\
\text { LWI } \\
\text { Severely materially deprived } \\
\text { Other }\end{array}$ \\
\hline HTH & General health & $\begin{array}{l}\text { Very good } \\
\text { Good } \\
\text { Fair } \\
\text { Bad } \\
\text { Very bad }\end{array}$ \\
\hline
\end{tabular}

${ }^{1}$ Low: Never in education, Pre-primary school,Primary school and Lower secondary school; Medium :Secondary school and Postsecondary school; High: Tertiary education (1st and 2nd stage). 


\begin{tabular}{|c|c|c|}
\hline Label & Variable name & Categories \\
\hline ROO & House/flat: number of rooms & $\begin{array}{l}1 \text { room } \\
2 \text { rooms } \\
3 \text { rooms } \\
4 \text { rooms } \\
5 \text { rooms } \\
6+\text { rooms }\end{array}$ \\
\hline TST & Tenure status & $\begin{array}{l}\text { Owner } \\
\text { Tenant or subtenant paying rent at prevailing / } \\
\text { market rate } \\
\text { Accommodation is rented at a reduced rate or } \\
\text { provided free }\end{array}$ \\
\hline DTY & Dwelling type & $\begin{array}{l}\text { Detached house } \\
\text { Semi-detached or terraced house } \\
\text { Apartment or flat }<10 \\
\text { Apartment or flat with } 10 \text { or more }\end{array}$ \\
\hline RCA & Reason for changing dwelling & $\begin{array}{l}\text { No change } \\
\text { Forced to leave. on termination of the contract } \\
\text { Forced to leave. in the absence of a formal } \\
\text { contract } \\
\text { Forced to leave because of eviction or distraint } \\
\text { Forced to leave for financial difficulties } \\
\text { Forced to leave for a family-related reason } \\
\text { Forced to leave for an employment-related } \\
\text { reasons } \\
\text { Forced to leave for some other reason }\end{array}$ \\
\hline TYPE & Household type & $\begin{array}{l}\text { One person household } \\
2 \text { adults both adults }<65 \text { years } \\
2 \text { adults . at least one adult } \geq 65 \text { years } \\
\text { Other without dependent children } \\
\text { Single parent and } \geq 1 \text { dependent children } \\
2 \text { adults. one dependent child } \\
2 \text { adults. two dependent children } \\
2 \text { adults and } \geq 3 \text { dependent children } \\
\text { Other households with dependent children } \\
\text { Other type }\end{array}$ \\
\hline HDI & Equivalized disposable income & $\begin{array}{l}\text { 1st quintile } \\
\text { 2nd quintile } \\
\text { 3rd quintile } \\
\text { 4th quintile } \\
\text { 5th quintile }\end{array}$ \\
\hline POI & Poverty indicator & $\begin{array}{l}\text { Not at risk of poverty } \\
\text { At risk of poverty }\end{array}$ \\
\hline SMD & Severely materially deprived household & $\begin{array}{l}\text { Not severely deprived } \\
\text { Severely deprived }\end{array}$ \\
\hline $\mathrm{HCO}$ & Financial burden of the total housing cost & $\begin{array}{l}\text { No housing cost } \\
\text { A heavy burden } \\
\text { Somewhat a burden } \\
\text { Not burden at all }\end{array}$ \\
\hline DEB & Debts for hire purchases or loans & $\begin{array}{l}\text { Non Debts } \\
\text { Debts }\end{array}$ \\
\hline WIS & Work intensity status & $\begin{array}{l}\text { WI }=0 \\
0<W I<0.5 \\
0.5 \leq W I<1 \\
W I=1\end{array}$ \\
\hline FAL & Family/children related allowances & $\begin{array}{l}\text { No } \\
\text { Yes }\end{array}$ \\
\hline AAL & $\begin{array}{l}\text { Social exclusion not elsewhere classified } \\
\text { - Allowances }\end{array}$ & $\begin{array}{l}\text { No } \\
\text { Yes }\end{array}$ \\
\hline
\end{tabular}




\begin{tabular}{|c|c|c|}
\hline Label & Variable name & Categories \\
\hline HAL & Housing allowances & $\begin{array}{l}\text { No } \\
\text { Yes }\end{array}$ \\
\hline ICT & Regular inter-household cash received & $\begin{array}{l}\text { No } \\
\text { Yes }\end{array}$ \\
\hline ALI & $\begin{array}{l}\text { Alimonies received (compulsory. } \\
\text { voluntary) }\end{array}$ & $\begin{array}{l}\text { No } \\
\text { Yes }\end{array}$ \\
\hline I16 & $\begin{array}{l}\text { Income received by people aged under } \\
16\end{array}$ & $\begin{array}{l}\text { No } \\
\text { Yes }\end{array}$ \\
\hline
\end{tabular}

Table A2 - Social capital indicators: Social behaviour (Source: EU-SILC 2009; Eurostat)

\begin{tabular}{|c|c|c|c|c|}
\hline Label & Variable name & Categories & Type of indicator & Source \\
\hline CRH & $\begin{array}{l}\text { In your local area are there any problems } \\
\text { of crime. violence or vandalism? }\end{array}$ & $\begin{array}{l}\text { Yes } \\
\text { No }\end{array}$ & Household (respondent) & EU-SILC \\
\hline CRC & $\begin{array}{l}\% \text { of total population suffering from } \\
\text { problems of crime. violence or vandalism }\end{array}$ & $\begin{array}{l}\text { High } \\
\text { Medium } \\
\text { Low }\end{array}$ & Community & Eurostat \\
\hline$C R R$ & $\begin{array}{l}\text { Crime recorded by the police: total crime } \\
\text { (Number of crimes per } 100 \text { inhabitants). }\end{array}$ & $\begin{array}{l}\text { High } \\
\text { Medium } \\
\text { Low }\end{array}$ & Community & Eurostat \\
\hline LTH & Litter lying around the neighbourhood & $\begin{array}{l}\text { Very frequently } \\
\text { Frequently } \\
\text { Sometimes } \\
\text { Rarely or never }\end{array}$ & Household (respondent) & EU-SILC \\
\hline$D M H$ & $\begin{array}{l}\text { Damaged public amenities in the } \\
\text { neighbourhood }\end{array}$ & $\begin{array}{l}\text { Very frequently } \\
\text { Frequently } \\
\text { Sometimes } \\
\text { Rarely or never }\end{array}$ & Household (respondent) & EU-SILC \\
\hline
\end{tabular}


Table A2 continued - Social capital indicators: Social relationships (Source: EU-SILC 2009)

\begin{tabular}{|c|c|c|}
\hline Label & Variable name & Categories \\
\hline $\mathrm{PHO}$ & Do you have a phone? (including mobile) & $\begin{array}{l}\text { No } \\
\text { Yes }\end{array}$ \\
\hline$T V C$ & Do you have a colour tv? & $\begin{array}{l}\text { No } \\
\text { Yes }\end{array}$ \\
\hline$P C$ & Do you have a computer? & $\begin{array}{l}\text { No } \\
\text { Yes }\end{array}$ \\
\hline CHI & $\begin{array}{l}\text { Number of hours of child care by grandparents. } \\
\text { others household members (outside parents). other } \\
\text { relatives. friends or neighbors (free of charge) (per } \\
\text { household member if less than } 12 \text { years old). }\end{array}$ & $\begin{array}{l}\text { None } \\
\text { Low } \\
\text { Medium } \\
\text { High } \\
\text { Not applicable }\end{array}$ \\
\hline$F A W$ & $\begin{array}{l}\text { Are there "family workers" in your family business? } \\
\text { (number) }\end{array}$ & $\begin{array}{l}\text { None } \\
1 \text { FAW } \\
2 \text { or more FAW } \\
\text { Not applicable }\end{array}$ \\
\hline INTC & Do you have an internet connection? & $\begin{array}{l}\text { No } \\
\text { Yes }\end{array}$ \\
\hline MEA & $\begin{array}{l}\text { Get-together with friends/relatives for a drink/a meal } \\
\text { at least once a month }\end{array}$ & $\begin{array}{l}\text { No } \\
\text { Yes }\end{array}$ \\
\hline$L E S$ & $\begin{array}{l}\text { Regularly participate in a leisure activity such as } \\
\text { sport. cinema. concert }\end{array}$ & $\begin{array}{l}\text { No } \\
\text { Yes }\end{array}$ \\
\hline$L 16$ & $\begin{array}{l}\text { Do your children under } 16 \text { participate in a regular } \\
\text { leisure activity (swimming. playing an instrument. } \\
\text { youth organizations. etc.)? }\end{array}$ & $\begin{array}{l}\text { No } \\
\text { Yes } \\
\text { Not applicable }\end{array}$ \\
\hline C16 & $\begin{array}{l}\text { Do your children under } 16 \text { have celebrations on } \\
\text { special occasions (birthdays. name days. religious } \\
\text { events )? }\end{array}$ & $\begin{array}{l}\text { No } \\
\text { Yes } \\
\text { Not applicable }\end{array}$ \\
\hline I16 & $\begin{array}{l}\text { Do your children under } 16 \text { invite friends round to } \\
\text { play and eat from time to time? }\end{array}$ & $\begin{array}{l}\text { No } \\
\text { Yes } \\
\text { Not applicable }\end{array}$ \\
\hline E16 & $\begin{array}{l}\text { Do your children under } 16 \text { participate in school trips } \\
\text { and school events that cost money? }\end{array}$ & $\begin{array}{l}\text { No } \\
\text { Yes } \\
\text { Not applicable }\end{array}$ \\
\hline 016 & $\begin{array}{l}\text { Do your children under } 16 \text { have an outdoor space in } \\
\text { the neighbourhood where they can play safely? }\end{array}$ & $\begin{array}{l}\text { No } \\
\text { Yes } \\
\text { Not applicable }\end{array}$ \\
\hline
\end{tabular}


Table A2 continued - Social capital indicators: Territorial context (Source: EU-SILC 2009)

\begin{tabular}{|c|c|c|c|c|}
\hline Label & Variable name & Categories & Type of indicator & Source \\
\hline $\mathrm{OCH}$ & Overcrowded household & $\begin{array}{l}\text { Yes } \\
\text { No }\end{array}$ & Household (respondent) & EU-SILC \\
\hline$O C C$ & Overcrowding rate & $\begin{array}{l}\text { High } \\
\text { Medium } \\
\text { Low }\end{array}$ & Community & Eurostat \\
\hline $\mathrm{H1H}$ & $\begin{array}{l}\text { Do you have any of the following problems related } \\
\text { to the place where you live? (Leaking roof. Dump } \\
\text { walls/floors/foundation. rot in windows frames or } \\
\text { floor) }\end{array}$ & $\begin{array}{l}\text { Yes } \\
\text { No }\end{array}$ & Household (respondent) & EU-SILC \\
\hline H1C & $\begin{array}{l}\text { Housing deprivation rate: } \% \text { of total population } \\
\text { living in a dwelling with a leaking roof. damp walls. } \\
\text { floors or foundation. or rot in window frames of } \\
\text { floor. }\end{array}$ & $\begin{array}{l}\text { High } \\
\text { Medium } \\
\text { Low }\end{array}$ & Community & Eurostat \\
\hline $\mathrm{H} 2 \mathrm{H}$ & $\begin{array}{l}\text { Is your dwelling too dark. meaning is there not } \\
\text { enough day-light coming through the windows? }\end{array}$ & $\begin{array}{l}\text { Yes } \\
\text { No }\end{array}$ & Household (respondent) & EU-SILC \\
\hline $\mathrm{H} 2 \mathrm{C}$ & $\begin{array}{l}\text { Housing deprivation rate: } \% \text { of total population } \\
\text { considering their dwelling too dark }\end{array}$ & $\begin{array}{l}\text { High } \\
\text { Medium } \\
\text { Low }\end{array}$ & Community & Eurostat \\
\hline $\mathrm{H3H}$ & $\begin{array}{l}\text { Do you have too much noise in your dwelling from } \\
\text { neighbors or from outside (traffic. business. } \\
\text { factory)? }\end{array}$ & $\begin{array}{l}\text { Yes } \\
\text { No }\end{array}$ & Household (respondent) & EU-SILC \\
\hline H3C & $\begin{array}{l}\text { Environment of the dwelling: \% of total population } \\
\text { suffering noise from neighbors or from the street. }\end{array}$ & $\begin{array}{l}\text { High } \\
\text { Medium } \\
\text { Low }\end{array}$ & Community & Eurostat \\
\hline $\mathrm{H} 4 \mathrm{H}$ & $\begin{array}{l}\text { Pollution. grime or other environmental problems in } \\
\text { the local area such as smoke. dust. unpleasant smells } \\
\text { or polluted water }\end{array}$ & $\begin{array}{l}\text { Yes } \\
\text { No }\end{array}$ & Household (respondent) & EU-SILC \\
\hline $\mathrm{H} 4 \mathrm{C}$ & $\begin{array}{l}\text { Environment of the dwelling: \% of total population } \\
\text { suffering from pollution. grime or other } \\
\text { environmental problems. }\end{array}$ & $\begin{array}{l}\text { High } \\
\text { Medium } \\
\text { Low }\end{array}$ & Community & Eurostat \\
\hline HOT & Place to live with hot running water & $\begin{array}{l}\text { No } \\
\text { Yes }\end{array}$ & Household (respondent) & EU-SILC \\
\hline $\mathrm{SHO}$ & Shortage of space in the dwelling & $\begin{array}{l}\text { Yes } \\
\text { No }\end{array}$ & Household (respondent) & EU-SILC \\
\hline SQMTS & Size of dwelling in sq metres & $\begin{array}{l}<=50 \\
50-\mid 70 \\
70-\mid 90 \\
90-\mid 120 \\
>120\end{array}$ & Household (respondent) & EU-SILC \\
\hline$A P 1$ & Greenhouse gas emission (in $\mathrm{CO}_{2}$ equivalent). & $\begin{array}{l}\text { High } \\
\text { Medium } \\
\text { Low }\end{array}$ & Community & Eurostat \\
\hline$A P 2$ & $\begin{array}{l}\text { Urban population exposure to air pollution by ozone } \\
\text { (micrograms per cubic meter). }\end{array}$ & $\begin{array}{l}\text { High } \\
\text { Medium } \\
\text { Low }\end{array}$ & Community & Eurostat \\
\hline AP3 & $\begin{array}{l}\text { Urban population exposure to air pollution by } \\
\text { particulate matter (micrograms per cubic meter). }\end{array}$ & $\begin{array}{l}\text { High } \\
\text { Medium } \\
\text { Low }\end{array}$ & Community & Eurostat \\
\hline
\end{tabular}


A3 - Parameters estimates from model M3

Number of obs = 204739; Log Likelihhod=-248338.72

Category 'With great difficulty'

\begin{tabular}{|c|c|c|c|c|c|c|c|c|c|}
\hline Predictor_category & Estimate & s.e. & $\mathrm{z}$ & $p$-value & Predictor_category & Estimate & s.e. & z & $p$-value \\
\hline Age_25-29 & -0.30 & 0.03 & -8.89 & 0.00 & HDI_4 & 1.01 & 0.05 & 20.42 & 0.00 \\
\hline Age_30-34 & -0.29 & 0.05 & -6.12 & 0.00 & HDI_5 & 1.59 & 0.06 & 24.90 & 0.00 \\
\hline Age_35-39 & -0.35 & 0.05 & -7.60 & 0.00 & POI_2 & -0.29 & 0.02 & -11.78 & 0.00 \\
\hline Age_40-44 & -0.34 & 0.04 & -7.74 & 0.00 & SMD_2 & -1.31 & 0.02 & -59.01 & 0.00 \\
\hline Age_45-49 & -0.39 & 0.04 & -9.21 & 0.00 & HCO_2/3 & -2.21 & 0.02 & -104.83 & 0.00 \\
\hline Age_50-54 & -0.27 & 0.04 & -6.50 & 0.00 & DEB_2 & -0.42 & 0.02 & -19.71 & 0.00 \\
\hline Age_55-59 & -0.31 & 0.04 & -7.33 & 0.00 & FAL_2 & -0.13 & 0.03 & -5.05 & 0.00 \\
\hline Age_60-64 & -0.15 & 0.03 & -4.41 & 0.00 & AAL_2 & -0.21 & 0.03 & -6.78 & 0.00 \\
\hline Age_65-79 & -0.01 & 0.04 & -0.39 & 0.69 & HAL_2 & -0.17 & 0.02 & -8.70 & 0.00 \\
\hline Age_80+ & 0.11 & 0.05 & 2.12 & 0.03 & ICT_2 & -0.40 & 0.03 & -13.40 & 0.00 \\
\hline Gender_F & 0.00 & 0.02 & 0.15 & 0.88 & I16_2 & -0.15 & 0.03 & -4.54 & 0.00 \\
\hline MST_married & 0.04 & 0.02 & 2.56 & 0.01 & Belgium & -0.08 & 0.09 & -0.90 & 0.37 \\
\hline MST_sep./div. & -0.26 & 0.03 & -9.03 & 0.00 & Bulgaria & 0.21 & 0.09 & 2.36 & 0.02 \\
\hline MST_widowed & -0.17 & 0.02 & -8.78 & 0.00 & Cyprus & -0.58 & 0.09 & -6.16 & 0.00 \\
\hline EDU_medium & 0.18 & 0.01 & 16.11 & 0.00 & Czech Rep. & 0.42 & 0.09 & 4.64 & 0.00 \\
\hline EDU_high & 0.39 & 0.03 & 12.44 & 0.00 & Germany & 0.94 & 0.10 & 9.60 & 0.00 \\
\hline EMP_unemployed & -0.71 & 0.02 & -33.23 & 0.00 & Denmark & -0.22 & 0.13 & -1.66 & 0.10 \\
\hline EMP_retired & -0.12 & 0.02 & -6.91 & 0.00 & Estonia & 0.48 & 0.10 & 4.69 & 0.00 \\
\hline EMP_inactive & -0.26 & 0.02 & -10.83 & 0.00 & Spain & -0.21 & 0.08 & -2.59 & 0.01 \\
\hline ROOM_2 & 0.04 & 0.04 & 1.04 & 0.30 & Finland & 0.77 & 0.11 & 7.05 & 0.00 \\
\hline ROOM_3 & 0.12 & 0.04 & 2.91 & 0.00 & France & 1.04 & 0.09 & 10.95 & 0.00 \\
\hline ROOM_4 & 0.20 & 0.04 & 4.49 & 0.00 & Greece & -1.08 & 0.08 & -12.91 & 0.00 \\
\hline ROOM_5 & 0.26 & 0.05 & 5.21 & 0.00 & Hungary & -0.07 & 0.09 & -0.83 & 0.41 \\
\hline ROOM_6+ & 0.37 & 0.05 & 6.85 & 0.00 & Ireland & -0.73 & 0.10 & -7.49 & 0.00 \\
\hline TST_tenant & -0.24 & 0.03 & -8.13 & 0.00 & Italy & -0.01 & 0.08 & -0.06 & 0.95 \\
\hline TST_reduced & -0.20 & 0.02 & -9.53 & 0.00 & Lithuania & 0.87 & 0.10 & 8.84 & 0.00 \\
\hline TST_free & -0.09 & 0.03 & -2.74 & 0.01 & Luxemburg & 1.15 & 0.13 & 8.75 & 0.00 \\
\hline DTY_2 & 0.04 & 0.01 & 3.05 & 0.00 & Latvia & 0.52 & 0.09 & 5.72 & 0.00 \\
\hline DTY_3 & 0.08 & 0.02 & 5.52 & 0.00 & Malta & -0.39 & 0.10 & -4.06 & 0.00 \\
\hline DTY_4 & 0.01 & 0.02 & 0.29 & 0.77 & Netherlands & 0.19 & 0.11 & 1.76 & 0.08 \\
\hline TYPE_2 & 0.01 & 0.03 & 0.42 & 0.68 & Poland & 0.18 & 0.09 & 2.07 & 0.04 \\
\hline TYPE_3 & 0.06 & 0.03 & 1.85 & 0.07 & Portugal & -1.00 & 0.09 & -11.40 & 0.00 \\
\hline TYPE_4 & -0.19 & 0.03 & -5.65 & 0.00 & Romania & 0.59 & 0.09 & 6.42 & 0.00 \\
\hline TYPE_5 & -0.46 & 0.03 & -15.77 & 0.00 & Sweden & -0.03 & 0.12 & -0.28 & 0.78 \\
\hline TYPE_6 & -0.34 & 0.02 & -14.63 & 0.00 & Slovenia & 0.78 & 0.09 & 8.86 & 0.00 \\
\hline TYPE_7 & -0.43 & 0.03 & -16.62 & 0.00 & Slovakia & 0.36 & 0.10 & 3.73 & 0.00 \\
\hline TYPE_8 & -0.60 & 0.03 & -18.71 & 0.00 & UK & 0.31 & 0.09 & 3.34 & 0.00 \\
\hline TYPE_9 & -0.56 & 0.03 & -21.31 & 0.00 & $\mathrm{tcm}$ & 1.39 & 0.11 & 12.80 & 0.00 \\
\hline TYPE_10 & -0.04 & 0.16 & -0.24 & 0.81 & $\mathrm{srm}$ & 1.99 & 0.06 & 33.33 & 0.00 \\
\hline HDI_2 & 0.37 & 0.03 & 12.78 & 0.00 & sbmedia & 0.26 & 0.05 & 5.62 & 0.00 \\
\hline HDI_3 & 0.64 & 0.04 & 15.64 & 0.00 & constant & -2.02 & 0.21 & -9.69 & 0.00 \\
\hline
\end{tabular}


Category 'With difficulty'

\begin{tabular}{|c|c|c|c|c|c|c|c|c|c|}
\hline Predictor_category & Estimate & s.e. & z & $p$-value & Predictor_category & Estimate & s.e. & z & $p$-value \\
\hline Age_25-29 & -0.30 & 0.03 & -8.89 & 0.00 & HDI_4 & 1.25 & 0.04 & 35.51 & 0.00 \\
\hline Age_30-34 & -0.32 & 0.04 & -8.19 & 0.00 & HDI_5 & 1.89 & 0.04 & 45.32 & 0.00 \\
\hline Age_35-39 & -0.37 & 0.04 & -9.75 & 0.00 & POI_2 & -0.18 & 0.02 & -8.99 & 0.00 \\
\hline Age_40-44 & -0.37 & 0.04 & -10.04 & 0.00 & SMD_2 & -1.49 & 0.02 & -61.19 & 0.00 \\
\hline Age_45-49 & -0.40 & 0.04 & -11.11 & 0.00 & HCO_2/3 & -1.99 & 0.01 & -144.32 & 0.00 \\
\hline Age_50-54 & -0.36 & 0.04 & -9.94 & 0.00 & DEB_2 & -0.38 & 0.02 & -24.83 & 0.00 \\
\hline Age_55-59 & -0.30 & 0.04 & -8.10 & 0.00 & FAL_2 & -0.21 & 0.02 & -11.01 & 0.00 \\
\hline Age_60-64 & -0.15 & 0.03 & -4.41 & 0.00 & AAL_2 & -0.24 & 0.03 & -8.81 & 0.00 \\
\hline Age_65-79 & -0.01 & 0.04 & -0.39 & 0.69 & HAL_2 & -0.17 & 0.02 & -8.70 & 0.00 \\
\hline Age_80+ & 0.10 & 0.04 & 2.26 & 0.02 & ICT_2 & -0.28 & 0.03 & -10.93 & 0.00 \\
\hline Gender_F & -0.02 & 0.01 & -1.58 & 0.12 & |16_2 & -0.15 & 0.03 & -4.54 & 0.00 \\
\hline MST_married & 0.04 & 0.02 & 2.56 & 0.01 & Belgium & -0.16 & 0.06 & -2.63 & 0.01 \\
\hline MST_sep./div. & -0.23 & 0.02 & -9.59 & 0.00 & Bulgaria & -0.39 & 0.07 & -5.92 & 0.00 \\
\hline MST_widowed & -0.17 & 0.02 & -8.78 & 0.00 & Cyprus & -0.95 & 0.07 & -14.21 & 0.00 \\
\hline EDU_medium & 0.18 & 0.01 & 16.11 & 0.00 & Czech Rep. & -0.17 & 0.06 & -2.94 & 0.00 \\
\hline EDU_high & 0.50 & 0.02 & 24.41 & 0.00 & Germany & 1.01 & 0.06 & 16.12 & 0.00 \\
\hline EMP_unemployed & -0.71 & 0.02 & -33.23 & 0.00 & Denmark & -0.04 & 0.08 & -0.56 & 0.57 \\
\hline EMP_retired & -0.12 & 0.02 & -6.91 & 0.00 & Estonia & 0.56 & 0.07 & 8.34 & 0.00 \\
\hline EMP_inactive & -0.21 & 0.02 & -11.00 & 0.00 & Spain & -0.05 & 0.05 & -0.95 & 0.34 \\
\hline ROOM_2 & 0.06 & 0.03 & 1.88 & 0.06 & Finland & 0.92 & 0.07 & 13.12 & 0.00 \\
\hline ROOM_3 & 0.14 & 0.03 & 4.11 & 0.00 & France & 0.18 & 0.06 & 3.25 & 0.00 \\
\hline ROOM_4 & 0.21 & 0.04 & 5.93 & 0.00 & Greece & -1.67 & 0.06 & -29.65 & 0.00 \\
\hline ROOM_5 & 0.30 & 0.04 & 7.86 & 0.00 & Hungary & -0.59 & 0.06 & -9.82 & 0.00 \\
\hline ROOM_6+ & 0.42 & 0.04 & 10.10 & 0.00 & Ireland & -0.72 & 0.07 & -10.96 & 0.00 \\
\hline TST_tenant & -0.24 & 0.02 & -10.72 & 0.00 & Italy & 0.02 & 0.05 & 0.48 & 0.63 \\
\hline TST_reduced & -0.20 & 0.02 & -9.53 & 0.00 & Lithuania & 0.16 & 0.07 & 2.45 & 0.01 \\
\hline TST_free & -0.04 & 0.03 & -1.56 & 0.12 & Luxemburg & 1.08 & 0.08 & 13.44 & 0.00 \\
\hline DTY_2 & 0.04 & 0.01 & 3.05 & 0.00 & Latvia & -0.21 & 0.06 & -3.35 & 0.00 \\
\hline DTY_3 & 0.08 & 0.02 & 5.52 & 0.00 & Malta & -0.69 & 0.07 & -10.26 & 0.00 \\
\hline DTY_4 & 0.09 & 0.02 & 5.14 & 0.00 & Netherlands & 0.05 & 0.06 & 0.80 & 0.42 \\
\hline TYPE_2 & -0.01 & 0.02 & -0.57 & 0.57 & Poland & 0.20 & 0.06 & 3.41 & 0.00 \\
\hline TYPE_3 & 0.02 & 0.02 & 0.68 & 0.49 & Portugal & -0.89 & 0.06 & -14.79 & 0.00 \\
\hline TYPE_4 & -0.27 & 0.03 & -10.58 & 0.00 & Romania & 0.41 & 0.06 & 6.44 & 0.00 \\
\hline TYPE_5 & -0.46 & 0.03 & -15.77 & 0.00 & Sweden & 0.44 & 0.08 & 5.70 & 0.00 \\
\hline TYPE_6 & -0.34 & 0.02 & -14.63 & 0.00 & Slovenia & 0.30 & 0.06 & 5.30 & 0.00 \\
\hline TYPE_7 & -0.43 & 0.03 & -16.62 & 0.00 & Slovakia & 0.02 & 0.06 & 0.33 & 0.74 \\
\hline TYPE_8 & -0.60 & 0.03 & -18.71 & 0.00 & UK & 0.45 & 0.06 & 7.37 & 0.00 \\
\hline TYPE_9 & -0.56 & 0.03 & -21.31 & 0.00 & $\mathrm{tcm}$ & 1.33 & 0.09 & 15.24 & 0.00 \\
\hline TYPE_10 & -0.27 & 0.12 & -2.16 & 0.03 & $\mathrm{srm}$ & 1.99 & 0.05 & 44.04 & 0.00 \\
\hline HDI_2 & 0.47 & 0.02 & 21.94 & 0.00 & sbmedia & 0.24 & 0.04 & 6.87 & 0.00 \\
\hline HDI_3 & 0.85 & 0.03 & 28.43 & 0.00 & constant & -3.92 & 0.16 & -23.90 & 0.00 \\
\hline
\end{tabular}


Table A3 continued

Category 'With some difficulty'

\begin{tabular}{|c|c|c|c|c|c|c|c|c|c|}
\hline Predictor_category & Estimate & s.e. & z & $p$-value & Predictor_category & Estimate & s.e. & z & $p$-value \\
\hline Age_25-29 & -0.30 & 0.03 & -8.89 & 0.00 & HDI_4 & 1.68 & 0.03 & 48.37 & 0.00 \\
\hline Age_30-34 & -0.37 & 0.04 & -10.16 & 0.00 & HDI_5 & 2.47 & 0.04 & 65.42 & 0.00 \\
\hline Age_35-39 & -0.36 & 0.04 & -9.91 & 0.00 & POI_2 & 0.01 & 0.02 & 0.59 & 0.56 \\
\hline Age_40-44 & -0.41 & 0.04 & -11.51 & 0.00 & SMD_2 & -1.97 & 0.06 & -33.62 & 0.00 \\
\hline Age_45-49 & -0.36 & 0.04 & -10.15 & 0.00 & HCO_2/3 & -1.95 & 0.02 & -119.87 & 0.00 \\
\hline Age_50-54 & -0.38 & 0.04 & -10.84 & 0.00 & DEB_2 & -0.52 & 0.01 & -36.44 & 0.00 \\
\hline Age_55-59 & -0.28 & 0.04 & -7.86 & 0.00 & FAL_2 & -0.27 & 0.02 & -14.06 & 0.00 \\
\hline Age_60-64 & -0.15 & 0.03 & -4.41 & 0.00 & AAL_2 & -0.34 & 0.03 & -11.24 & 0.00 \\
\hline Age_65-79 & -0.01 & 0.04 & -0.39 & 0.69 & HAL_2 & -0.17 & 0.02 & -8.70 & 0.00 \\
\hline Age_80+ & 0.24 & 0.04 & 5.70 & 0.00 & ICT_2 & -0.24 & 0.03 & -8.84 & 0.00 \\
\hline Gender_F & -0.11 & 0.01 & -8.70 & 0.00 & I16_2 & -0.15 & 0.03 & -4.54 & 0.00 \\
\hline MST_married & 0.04 & 0.02 & 2.56 & 0.01 & Belgium & 0.25 & 0.05 & 5.58 & 0.00 \\
\hline MST_sep./div. & -0.25 & 0.02 & -10.74 & 0.00 & Bulgaria & -0.62 & 0.07 & -8.63 & 0.00 \\
\hline MST_widowed & -0.17 & 0.02 & -8.78 & 0.00 & Cyprus & -0.75 & 0.06 & -12.24 & 0.00 \\
\hline EDU_medium & 0.18 & 0.01 & 16.11 & 0.00 & Czech Rep. & 0.01 & 0.04 & 0.28 & 0.78 \\
\hline EDU_high & 0.57 & 0.02 & 33.59 & 0.00 & Germany & 1.68 & 0.04 & 37.72 & 0.00 \\
\hline EMP_unemployed & -0.71 & 0.02 & -33.23 & 0.00 & Denmark & 0.54 & 0.05 & 10.05 & 0.00 \\
\hline EMP_retired & -0.12 & 0.02 & -6.91 & 0.00 & Estonia & 0.09 & 0.05 & 1.70 & 0.09 \\
\hline EMP_inactive & -0.15 & 0.02 & -7.48 & 0.00 & Spain & 0.28 & 0.04 & 6.84 & 0.00 \\
\hline ROOM_2 & -0.17 & 0.04 & -4.69 & 0.00 & Finland & 0.96 & 0.05 & 19.92 & 0.00 \\
\hline ROOM_3 & -0.09 & 0.04 & -2.45 & 0.01 & France & -0.70 & 0.04 & -17.99 & 0.00 \\
\hline ROOM_4 & -0.02 & 0.04 & -0.52 & 0.60 & Greece & -1.11 & 0.05 & -22.76 & 0.00 \\
\hline ROOM_5 & 0.08 & 0.04 & 2.14 & 0.03 & Hungary & -0.84 & 0.05 & -15.49 & 0.00 \\
\hline ROOM_6+ & 0.19 & 0.04 & 4.75 & 0.00 & Ireland & -1.00 & 0.05 & -20.12 & 0.00 \\
\hline TST_tenant & -0.29 & 0.02 & -13.81 & 0.00 & Italy & -0.35 & 0.04 & -9.02 & 0.00 \\
\hline TST_reduced & -0.20 & 0.02 & -9.53 & 0.00 & Lithuania & -0.99 & 0.06 & -16.06 & 0.00 \\
\hline TST_free & 0.03 & 0.03 & 1.31 & 0.19 & Luxemburg & 1.35 & 0.06 & 23.63 & 0.00 \\
\hline DTY_2 & 0.04 & 0.01 & 3.05 & 0.00 & Latvia & -0.12 & 0.05 & -2.15 & 0.03 \\
\hline DTY_3 & 0.08 & 0.02 & 5.52 & 0.00 & Malta & -0.44 & 0.06 & -7.27 & 0.00 \\
\hline DTY_4 & 0.14 & 0.02 & 8.68 & 0.00 & Netherlands & 0.98 & 0.05 & 21.50 & 0.00 \\
\hline TYPE_2 & -0.03 & 0.02 & -1.49 & 0.14 & Poland & 0.30 & 0.05 & 6.26 & 0.00 \\
\hline TYPE_3 & -0.03 & 0.02 & -1.52 & 0.13 & Portugal & -0.75 & 0.05 & -14.24 & 0.00 \\
\hline TYPE_4 & -0.36 & 0.02 & -14.36 & 0.00 & Romania & 0.25 & 0.06 & 4.15 & 0.00 \\
\hline TYPE_5 & -0.46 & 0.03 & -15.77 & 0.00 & Sweden & 1.17 & 0.05 & 21.39 & 0.00 \\
\hline TYPE_6 & -0.34 & 0.02 & -14.63 & 0.00 & Slovenia & -0.10 & 0.04 & -2.21 & 0.03 \\
\hline TYPE_7 & -0.43 & 0.03 & -16.62 & 0.00 & Slovakia & -0.15 & 0.05 & -2.76 & 0.01 \\
\hline TYPE_8 & -0.60 & 0.03 & -18.71 & 0.00 & UK & 0.69 & 0.04 & 15.33 & 0.00 \\
\hline TYPE_9 & -0.56 & 0.03 & -21.31 & 0.00 & $\mathrm{tcm}$ & 1.72 & 0.09 & 18.75 & 0.00 \\
\hline TYPE_10 & -0.44 & 0.12 & -3.74 & 0.00 & srm & 1.65 & 0.04 & 37.84 & 0.00 \\
\hline HDI_2 & 0.65 & 0.02 & 26.57 & 0.00 & sbmedia & 0.24 & 0.04 & 6.83 & 0.00 \\
\hline HDI_3 & 1.18 & 0.03 & 38.93 & 0.00 & constant & -6.30 & 0.17 & -37.81 & 0.00 \\
\hline
\end{tabular}




\begin{tabular}{|c|c|c|c|c|c|c|c|c|c|}
\hline Predictor_category & Estimate & s.e. & z & $p$-value & Predictor_category & Estimate & s.e. & $z$ & $p$-value \\
\hline Age_25-29 & -0.30 & 0.03 & -8.89 & 0.00 & HDI_4 & 1.62 & 0.05 & 30.97 & 0.00 \\
\hline Age_30-34 & -0.40 & 0.04 & -9.91 & 0.00 & HDI_5 & 2.38 & 0.05 & 44.19 & 0.00 \\
\hline Age_35-39 & -0.35 & 0.04 & -8.82 & 0.00 & POI_2 & 0.20 & 0.03 & 5.83 & 0.00 \\
\hline Age_40-44 & -0.40 & 0.04 & -10.12 & 0.00 & SMD_2 & -1.95 & 0.12 & -15.66 & 0.00 \\
\hline Age_45-49 & -0.36 & 0.04 & -9.49 & 0.00 & HCO_2/3 & -1.84 & 0.03 & -67.02 & 0.00 \\
\hline Age_50-54 & -0.31 & 0.04 & -8.22 & 0.00 & DEB_2 & -0.52 & 0.02 & -30.12 & 0.00 \\
\hline Age_55-59 & -0.22 & 0.04 & -5.85 & 0.00 & FAL_2 & -0.26 & 0.02 & -10.68 & 0.00 \\
\hline Age_60-64 & -0.15 & 0.03 & -4.41 & 0.00 & AAL_2 & -0.14 & 0.04 & -3.54 & 0.00 \\
\hline Age_65-79 & -0.01 & 0.04 & -0.39 & 0.69 & HAL_2 & -0.17 & 0.02 & -8.70 & 0.00 \\
\hline Age_80+ & 0.25 & 0.05 & 5.33 & 0.00 & ICT_2 & -0.19 & 0.04 & -5.25 & 0.00 \\
\hline Gender_F & -0.12 & 0.01 & -8.68 & 0.00 & 116_2 & -0.15 & 0.03 & -4.54 & 0.00 \\
\hline MST_married & 0.04 & 0.02 & 2.56 & 0.01 & Belgium & 0.31 & 0.05 & 6.64 & 0.00 \\
\hline MST_sep./div. & -0.19 & 0.03 & -7.23 & 0.00 & Bulgaria & -0.80 & 0.13 & -6.42 & 0.00 \\
\hline MST_widowed & -0.17 & 0.02 & -8.78 & 0.00 & Cyprus & -0.81 & 0.08 & -9.75 & 0.00 \\
\hline EDU_medium & 0.18 & 0.01 & 16.11 & 0.00 & Czech Rep. & -0.08 & 0.06 & -1.39 & 0.16 \\
\hline EDU_high & 0.54 & 0.02 & 30.31 & 0.00 & Germany & 0.56 & 0.04 & 13.20 & 0.00 \\
\hline EMP_unemployed & -0.71 & 0.02 & -33.23 & 0.00 & Denmark & 0.68 & 0.05 & 13.28 & 0.00 \\
\hline EMP_retired & -0.12 & 0.02 & -6.91 & 0.00 & Estonia & -0.49 & 0.08 & -6.51 & 0.00 \\
\hline EMP_inactive & -0.11 & 0.02 & -4.65 & 0.00 & Spain & -0.12 & 0.05 & -2.60 & 0.01 \\
\hline ROOM_2 & -0.10 & 0.05 & -2.09 & 0.04 & Finland & 0.55 & 0.05 & 11.12 & 0.00 \\
\hline ROOM_3 & -0.07 & 0.05 & -1.37 & 0.17 & France & -0.93 & 0.05 & -20.42 & 0.00 \\
\hline ROOM_4 & 0.01 & 0.05 & 0.12 & 0.90 & Greece & -0.90 & 0.06 & -13.99 & 0.00 \\
\hline ROOM_5 & 0.14 & 0.05 & 2.63 & 0.01 & Hungary & -1.36 & 0.09 & -14.41 & 0.00 \\
\hline ROOM_6+ & 0.28 & 0.05 & 5.25 & 0.00 & Ireland & -1.05 & 0.06 & -17.87 & 0.00 \\
\hline TST_tenant & -0.20 & 0.02 & -8.49 & 0.00 & Italy & -0.78 & 0.05 & -16.58 & 0.00 \\
\hline TST_reduced & -0.20 & 0.02 & -9.53 & 0.00 & Lithuania & -1.48 & 0.11 & -13.20 & 0.00 \\
\hline TST_free & 0.08 & 0.04 & 2.29 & 0.02 & Luxemburg & 0.89 & 0.05 & 16.93 & 0.00 \\
\hline DTY_2 & 0.04 & 0.01 & 3.05 & 0.00 & Latvia & -0.97 & 0.10 & -10.01 & 0.00 \\
\hline DTY_3 & 0.08 & 0.02 & 5.52 & 0.00 & Malta & -0.83 & 0.09 & -9.36 & 0.00 \\
\hline DTY_4 & 0.20 & 0.02 & 9.80 & 0.00 & Netherlands & 1.59 & 0.04 & 35.74 & 0.00 \\
\hline TYPE_2 & -0.10 & 0.02 & -4.28 & 0.00 & Poland & 0.05 & 0.06 & 0.84 & 0.40 \\
\hline TYPE_3 & -0.12 & 0.03 & -4.43 & 0.00 & Portugal & -1.06 & 0.08 & -13.44 & 0.00 \\
\hline TYPE_4 & -0.42 & 0.03 & -13.59 & 0.00 & Romania & 0.28 & 0.08 & 3.32 & 0.00 \\
\hline TYPE_5 & -0.46 & 0.03 & -15.77 & 0.00 & Sweden & 0.45 & 0.05 & 9.03 & 0.00 \\
\hline TYPE_6 & -0.34 & 0.02 & -14.63 & 0.00 & Slovenia & -0.07 & 0.05 & -1.31 & 0.19 \\
\hline TYPE_7 & -0.43 & 0.03 & -16.62 & 0.00 & Slovakia & -0.70 & 0.09 & -8.16 & 0.00 \\
\hline TYPE_8 & -0.60 & 0.03 & -18.71 & 0.00 & UK & 0.13 & 0.05 & 2.71 & 0.01 \\
\hline TYPE_9 & -0.56 & 0.03 & -21.31 & 0.00 & $\mathrm{tcm}$ & 1.55 & 0.12 & 12.89 & 0.00 \\
\hline TYPE_10 & -0.08 & 0.14 & -0.59 & 0.55 & $\mathrm{srm}$ & 1.11 & 0.05 & 20.47 & 0.00 \\
\hline HDI_2 & 0.57 & 0.04 & 13.12 & 0.00 & sbmedia & 0.12 & 0.04 & 2.70 & 0.01 \\
\hline HDI_3 & 1.13 & 0.05 & 23.80 & 0.00 & constant & -6.67 & 0.22 & -30.83 & 0.00 \\
\hline
\end{tabular}


Category 'Easily'

\begin{tabular}{|c|c|c|c|c|c|c|c|c|c|}
\hline Predictor_category & Estimate & s.e. & $z$ & $p$-value & Predictor_category & Estimate & s.e. & $z$ & $p$-value \\
\hline Age_25-29 & -0.30 & 0.03 & -8.89 & 0.00 & HDI_4 & 1.59 & 0.12 & 13.22 & 0.00 \\
\hline Age_30-34 & -0.21 & 0.06 & -3.71 & 0.00 & HDI_5 & 2.54 & 0.12 & 21.03 & 0.00 \\
\hline Age_35-39 & -0.18 & 0.06 & -3.29 & 0.00 & POI_2 & 0.45 & 0.07 & 6.36 & 0.00 \\
\hline Age_40-44 & -0.23 & 0.05 & -4.29 & 0.00 & SMD_2 & -1.44 & 0.23 & -6.17 & 0.00 \\
\hline Age_45-49 & -0.23 & 0.05 & -4.36 & 0.00 & HCO_2/3 & -1.88 & 0.07 & -26.97 & 0.00 \\
\hline Age_50-54 & -0.23 & 0.05 & -4.57 & 0.00 & DEB_2 & -0.51 & 0.03 & -17.88 & 0.00 \\
\hline Age_55-59 & -0.18 & 0.05 & -3.58 & 0.00 & FAL_2 & -0.29 & 0.04 & -6.74 & 0.00 \\
\hline Age_60-64 & -0.15 & 0.03 & -4.41 & 0.00 & AAL_2 & -0.08 & 0.07 & -1.15 & 0.25 \\
\hline Age_65-79 & -0.01 & 0.04 & -0.39 & 0.69 & HAL_2 & -0.17 & 0.02 & -8.70 & 0.00 \\
\hline Age_80+ & 0.18 & 0.07 & 2.66 & 0.01 & ICT_2 & -0.24 & 0.07 & -3.56 & 0.00 \\
\hline Gender_F & -0.22 & 0.02 & -9.35 & 0.00 & $116 \_2$ & -0.15 & 0.03 & -4.54 & 0.00 \\
\hline MST_married & 0.04 & 0.02 & 2.56 & 0.01 & Belgium & -0.40 & 0.08 & -4.88 & 0.00 \\
\hline MST_sep./div. & -0.09 & 0.04 & -2.17 & 0.03 & Bulgaria & -2.12 & 0.51 & -4.17 & 0.00 \\
\hline MST_widowed & -0.17 & 0.02 & -8.78 & 0.00 & Cyprus & -1.07 & 0.18 & -6.12 & 0.00 \\
\hline EDU_medium & 0.18 & 0.01 & 16.11 & 0.00 & Czech Rep. & -0.88 & 0.13 & -6.67 & 0.00 \\
\hline EDU_high & 0.60 & 0.03 & 23.01 & 0.00 & Germany & 0.12 & 0.07 & 1.84 & 0.07 \\
\hline EMP_unemployed & -0.71 & 0.02 & -33.23 & 0.00 & Denmark & 0.57 & 0.08 & 7.28 & 0.00 \\
\hline EMP_retired & -0.12 & 0.02 & -6.91 & 0.00 & Estonia & -1.13 & 0.20 & -5.59 & 0.00 \\
\hline EMP_inactive & -0.19 & 0.04 & -4.28 & 0.00 & Spain & -1.18 & 0.10 & -12.21 & 0.00 \\
\hline ROOM_2 & -0.14 & 0.09 & -1.62 & 0.11 & Finland & 0.73 & 0.08 & 9.18 & 0.00 \\
\hline ROOM_3 & -0.17 & 0.09 & -2.00 & 0.05 & France & -1.45 & 0.09 & -16.04 & 0.00 \\
\hline ROOM_4 & -0.16 & 0.09 & -1.80 & 0.07 & Greece & -1.31 & 0.14 & -9.22 & 0.00 \\
\hline ROOM_5 & -0.06 & 0.09 & -0.69 & 0.49 & Hungary & -1.55 & 0.23 & -6.65 & 0.00 \\
\hline ROOM_6+ & 0.09 & 0.09 & 0.97 & 0.33 & Ireland & -0.79 & 0.10 & -7.96 & 0.00 \\
\hline TST_tenant & -0.23 & 0.04 & -6.30 & 0.00 & Italy & -1.45 & 0.10 & -14.99 & 0.00 \\
\hline TST_reduced & -0.20 & 0.02 & -9.53 & 0.00 & Lithuania & -3.66 & 0.71 & -5.14 & 0.00 \\
\hline TST_free & 0.15 & 0.08 & 1.99 & 0.05 & Luxemburg & 0.24 & 0.08 & 2.96 & 0.00 \\
\hline DTY_2 & 0.04 & 0.01 & 3.05 & 0.00 & Latvia & -2.05 & 0.32 & -6.30 & 0.00 \\
\hline DTY_3 & 0.08 & 0.02 & 5.52 & 0.00 & Malta & -1.31 & 0.23 & -5.75 & 0.00 \\
\hline DTY_4 & 0.19 & 0.03 & 5.57 & 0.00 & Netherlands & 0.70 & 0.07 & 10.63 & 0.00 \\
\hline TYPE_2 & -0.08 & 0.03 & -2.43 & 0.02 & Poland & -0.34 & 0.12 & -2.83 & 0.01 \\
\hline TYPE_3 & -0.10 & 0.04 & -2.42 & 0.02 & Portugal & -1.89 & 0.23 & -8.30 & 0.00 \\
\hline TYPE_4 & -0.49 & 0.06 & -8.68 & 0.00 & Romania & -0.57 & 0.23 & -2.52 & 0.01 \\
\hline TYPE_5 & -0.46 & 0.03 & -15.77 & 0.00 & Sweden & 1.05 & 0.08 & 13.80 & 0.00 \\
\hline TYPE_6 & -0.34 & 0.02 & -14.63 & 0.00 & Slovenia & -1.08 & 0.13 & -8.36 & 0.00 \\
\hline TYPE_7 & -0.43 & 0.03 & -16.62 & 0.00 & Slovakia & -0.86 & 0.20 & -4.29 & 0.00 \\
\hline TYPE_8 & -0.60 & 0.03 & -18.71 & 0.00 & UK & 0.33 & 0.08 & 4.37 & 0.00 \\
\hline TYPE_9 & -0.56 & 0.03 & -21.31 & 0.00 & $\mathrm{tcm}$ & 1.23 & 0.21 & 5.79 & 0.00 \\
\hline TYPE_10 & 0.03 & 0.21 & 0.13 & 0.90 & srm & 0.80 & 0.10 & 8.37 & 0.00 \\
\hline HDI_2 & 0.42 & 0.11 & 3.71 & 0.00 & sbmedia & -0.06 & 0.07 & -0.85 & 0.39 \\
\hline HDI_3 & 1.10 & 0.11 & 9.95 & 0.00 & constant & -7.06 & 0.39 & -18.21 & 0.00 \\
\hline
\end{tabular}

